\title{
A Narrative Review on the Characteristics and Treatment of Benign and Malignant Bone Tumors
}

\author{
Masoud Bahrami Frydoni1 ${ }^{1,2,3}$, Seyed Mokhtar Esmaeilnejad-Ganji ${ }^{1,2,3}$ \\ ${ }^{1}$ Mobility Impairment Research Center, Health Research Institute, Babol University of Medical Sciences, \\ Babol, Iran \\ ${ }^{2}$ Clinical Research Development Center, Shahid Beheshti Hospital, Babol University of Medical Sciences, \\ Babol, Iran \\ ${ }^{3}$ Department of Orthopedics, School of Medicine, Babol University of Medical Sciences, Babol, Iran
}

\section{SUMMARY}

Bone tumors, including benign and malignant lesions, are not metastatic; however, they may appear in any part of the body skeleton. Distal femur and proximal tibia (around the knee joint) are the most prevalent sites. Most benign bone tumors are cartilaginous tumors, known as osteochondromas. Based on the reports, benign bone tumors are more frequent than primary malignant ones. Malignant bone tumor is another type of bone tumor, which usually occurs within the first years of life. As a result, it can considerably affect the lives of patients and their families. These tumors consist of osteosarcoma, chondrosarcoma, and Ewing's sarcoma. This article discusses the epidemiology, characteristics, and treatment of the most important types of benign and malignant bone tumors. These data will be useful to the physicians and other health workers to better understand the conditions of bone tumors and their management.

Key words: bone tumor, malignant tumor, benign tumor

Corresponding author:

Masoud Bahrami Frydoni

e-mail: bahramimasoud478@gmail.com 


\section{EPIDEMIOLOGY AND \\ CLASSIFICATION OF BONE TUMORS}

Bone tumors are divided into two categories, which include primary (occurs in bone or bonederived tissues) and secondary (occurs in other areas and may metastasize to the skeleton) bone tumors (1). Prostate, breast, lung, thyroid, and kidney carcinomas are typically metastatic to bone (2). The estimated prevalence of secondary malignant bone tumors is as high as $50-100$ times the primary bone cancers. Primary bone tumors are divided into benign and malignant ones (3). Some types of bone tumors are benign, and may be progressive, cancerous, infectious, and inflammatory (4). Some other kinds of bone tumors are benign and not metastatic. Tumors may appear in any part of the body skeleton, but the most prevalent sites are the distal femur and proximal tibia (around the knee joint). They become hazardous if they grow in healthy bones. Based on the matrix produced by cancerous cells, these tumors are classified into eight types: osteochondroma, osteoma, osteoid osteoma, osteoblastoma, giant cell tumor, aneurysmal bone cyst, fibrous dysplasia, and enchondroma. Malignant bone tumors consist of osteosarcoma, chondrosarcoma, and Ewing's sarcoma (5).

Among various types of human neoplasms, the primary bone tumor is relatively uncommon. There is limited information regarding the prevalence and risk factors of primary bone tumors, which is associated with their features (3). Benign bone tumors are more prevalent than primary malignant ones. Therefore, benign tumors are apparently oftentimes underrated, as these mostly show no clinical symptoms and cannot be easily diagnosed. On the other hand, primary bone tumors are falsely known to be in the category of metastases, such as carcinoma, melanoma, or hematologic malignancies (plasmacytoma, etc.) (6). According to estimates, 2810 people were diagnosed with cancer $(1,620$ men and 1,190 women), and 1,490 people died from bone and joint cancer in 2011 . About $0.2 \%$ of bone cancer malignances in the USA are sarcomas. In addition, age-adjusted incidence rate is 0.9 per 100,000 people each year. The most common histological subsets are chondrosarcoma (30\% in men and $29 \%$ in women), osteosarcoma (16\% in men and $17 \%$ in women), Ewing's sarcoma (14\% in both), and chordoma ( $8 \%$ in men and $5 \%$ in women) (7).

\section{PRIMARY MALIGNANT BONE TUMORS}

\section{Osteosarcoma}

This type of bone tumor is a kind of mesenchymal tumor, which is highly malignant and the osteoid is produced by the tumor cells (8). It has the utmost prevalence of non-hematologic, primary, pe-

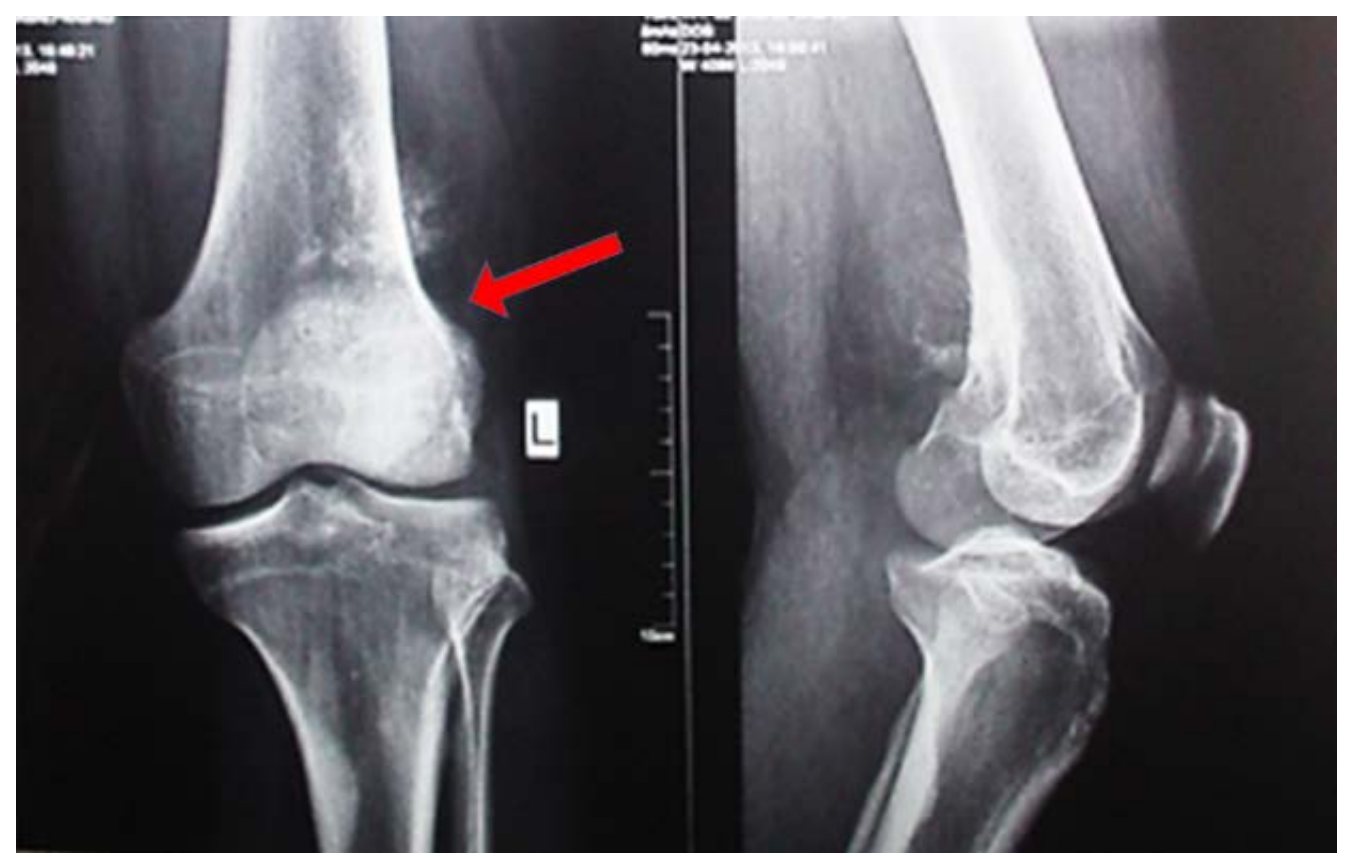

Figure 1. Osteosarcoma of the left distal femur 
diatric malignancy, which is prevalent in children aged 10-25 years. This type of sarcoma may appear in any bone. However, it is the most frequent in juxta-epiphyseal areas of long bones with rapid growth (9). Malignant spindle cells, generating osteoid and undeveloped bone, are a histopathologic sign of high-grade intramedullary osteosarcoma (10). Other signs include a disorganized structure of the bone, having a fine lacey trabecular pattern, and irregular osteoid masses, regardless of its normal bone formation (11). The classic type of osteosarcoma has fibrous or chondroid appearance with small osteoid masses. According to cytogenetic examinations, there are many complex chromosomal abnormalities that make osteosarcoma different in each person. Osteosarcoma differs from other sarcomas, for example, Ewing's sarcoma, synovial sarcoma, and alveolar rhabdomyosarcoma, in that it does not have any relationship with recurrent chromosomal rearrangements (12). There are different genetic alterations in osteosarcoma, which are shown by molecular analyses and include overexpressed oncogenes, including MDM2, and deactivation of p53 and retinoblastoma $(\mathrm{Rb})$ tumor suppresser genes (13, 14). It has been proved that invasive surgery combined with multi-agent chemotherapy can increase the long-term survival by up to $60 \%$ (15). Significantly, studies have shown that patients who were only treated with chemotherapy had a minor surviv- al rate of $20 \%$. Thus, it can be argued that a high fraction of osteosarcoma-cells show resistance to chemotherapy (16). Several studies have been conducted on surgical and medical treatments for osteosarcoma, but the survival rate is still below 30 years, and $40 \%$ of the patients expire due to cancer $(17,18)$. Figure 1 shows an osteosarcoma of the left distal femur.

\section{Chondrosarcoma}

It is a malignant mesenchymal tumor, which is distinguished by different cells that produce a chondroid matrix. Contrary to osteosarcoma and Ewing's sarcoma, this malignancy is most prevalent in adults aged $\geq 40$ (19). Chondrosarcoma mostly happens in the shoulder, hip girdle, and pelvis. This sarcoma is diagnosed at a late stage and has a poor prognosis due to its deep lesions (20). The most prevalent symptom is pain in the lesion area. Histopathologically, it has a continuum from various hyalines, such as hypocellular chondroid lesions with low mitotic action, to high-grade pleomorphic chondrosarcomas possibly having slight chondroid (21). In-vitro and in-vivo studies that blocked hedgehog signaling demonstrated a reduction in the growth of chondrosarcoma. It seems that P53 and RB alterations are related to high-grade chondrosarcomas with $96 \%$ involvement (22 - 25). It has been

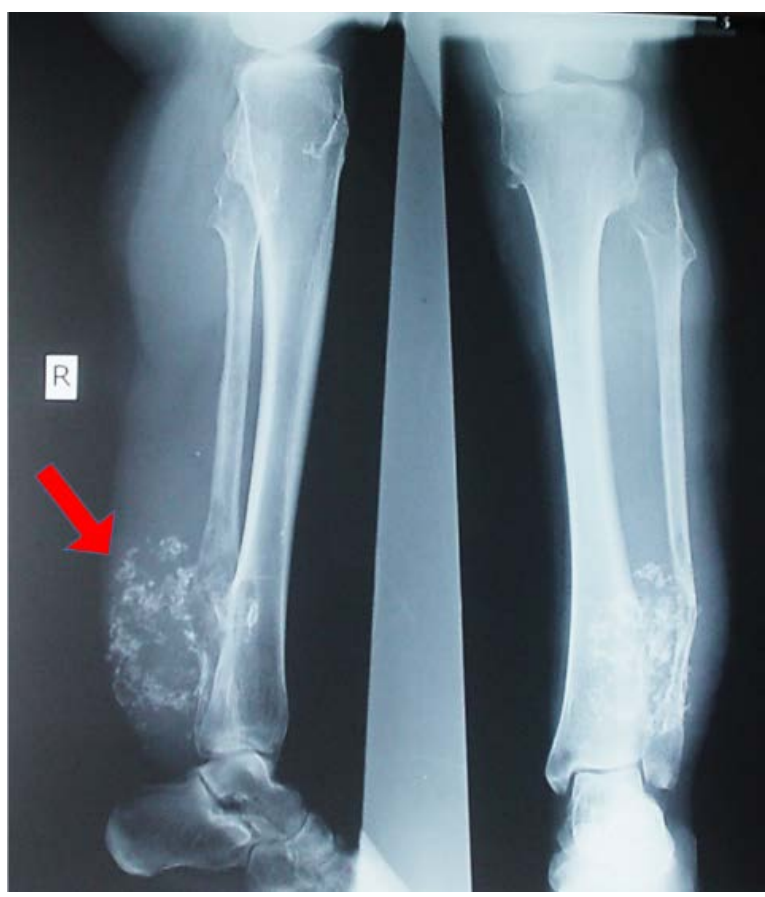

Figure 2. Chondrosarcoma of the right distal tibia 
stated that cyclin dependent kinase 4 (CDK4) expression is associated with chondrosarcoma progression. On the other hand, in-vitro studies indicated that CDK4 could be knocked down by short hairpin RNAs, leading to diminished colony formation. There are studies suggesting an epigenetic constituent to evaluate chondrosarcoma pathogenicity $(26,27)$. Both chemotherapy and radiotherapy have no effects on chondrosarcomas. It has been shown that chemotherapy resistance is caused by the multidrug-resistance gene (MDR-1) P-glycoprotein (28). Therefore, adjuvant or neo-adjuvant chemotherapy is not suggested for conventional treatment of chondrosarcoma. The standard cure involves surgical resection with no adjunct irradiation or chemotherapy. Metallic endoprostheses, allografts or alloprosthetic composites are usually needed in this treatment because all bone sarcomas have skeletal reconstruction $(29,30)$. Figure 2 shows a chondrosarcoma of the right distal tibia.

\section{Ewing's sarcoma}

This type of sarcoma is the second mostly prevalent primary malignant bone tumor in youngsters and teenagers, which is accompanied by small, round, and blue cells (31). Ewing's sarcoma is most present in long tubular bones such as femur, tibia, fibula, pelvic girdle, and the ribs (32). Histopathological characteristics include small round blue uniform non-differentiated cells having little cytoplasm (33). Ewing's tumors are positive in surface antigen CD99/MIC2 based on immunohistochemical studies. However, CD99 has no specificity to this sarcoma. CD99 may be present in lymphomas, leukemias, and rhabdomyosarcoma (34). Many patients with Ewing's sarcoma have (11; 22) (q24; q12) chromosomal translocation, encoding the EWS/FLI oncoprotein $(35,36)$. One of the theories for the tumor origin is that Ewing's sarcoma is a mesenchymal-derived tumor, implicating either neural ectoderm or mesenchymal stem cells (MSCs). For instance, neuroectodermal surface antigens are expressed on the Ewing's cells, which supports the neuroectodermal origin (37). Some other studies explained that MSCs or progenitor cells derive from Ewing's sarcoma. The cell of origin is still unknown, despite the fascinating available data (38).

A standard neo-adjuvant chemotherapy for the treatment of Ewing's sarcoma includes vincristine, cyclophosphamide, and doxorubicin by alternation with etoposide and ifosfamide in combination with irradiation, operation, or both (39). Event-free survivability and general survivability are respectively $65 \%$ and $82 \%$ in patients having localized disease, and $25 \%$ and $39 \%$ in patients with recognizable metastasis. The latest studies suggest intensive chemotherapy within a more shortened interval, with the intensification of alkylating agents (40). Surgical approach involves the resection

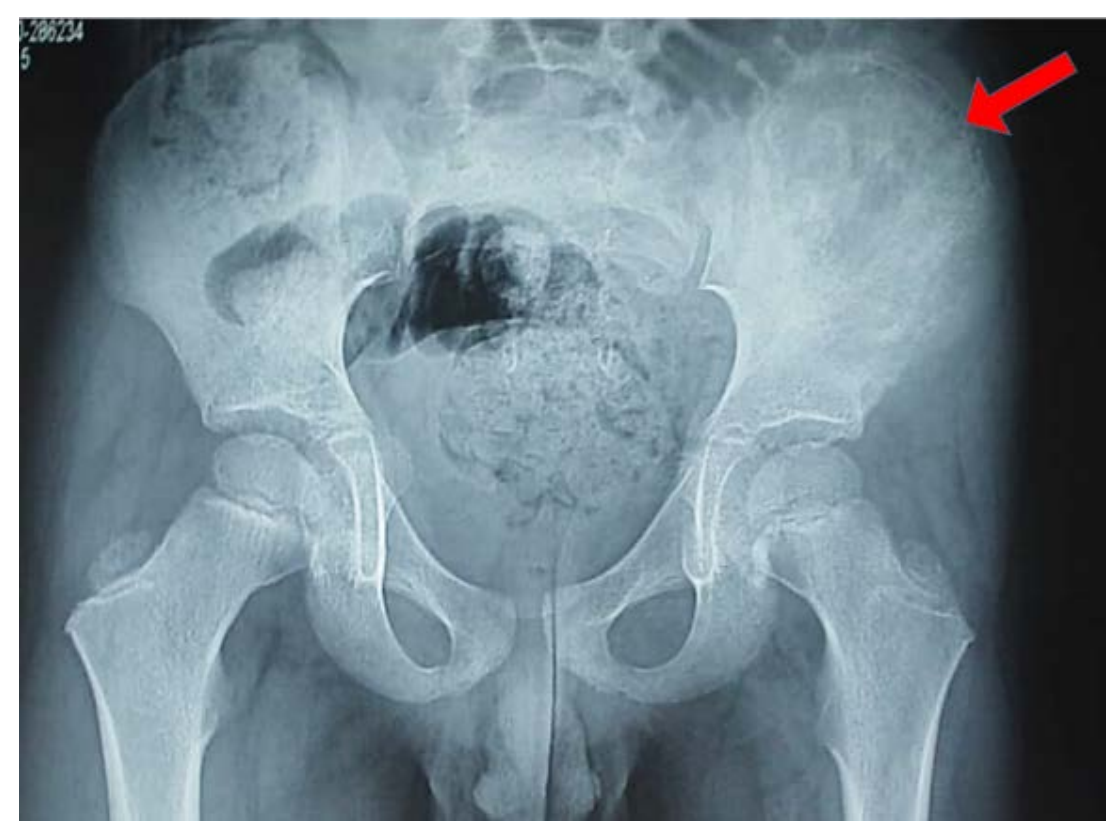

Figure 3. Ewing's sarcoma of the left pelvis 


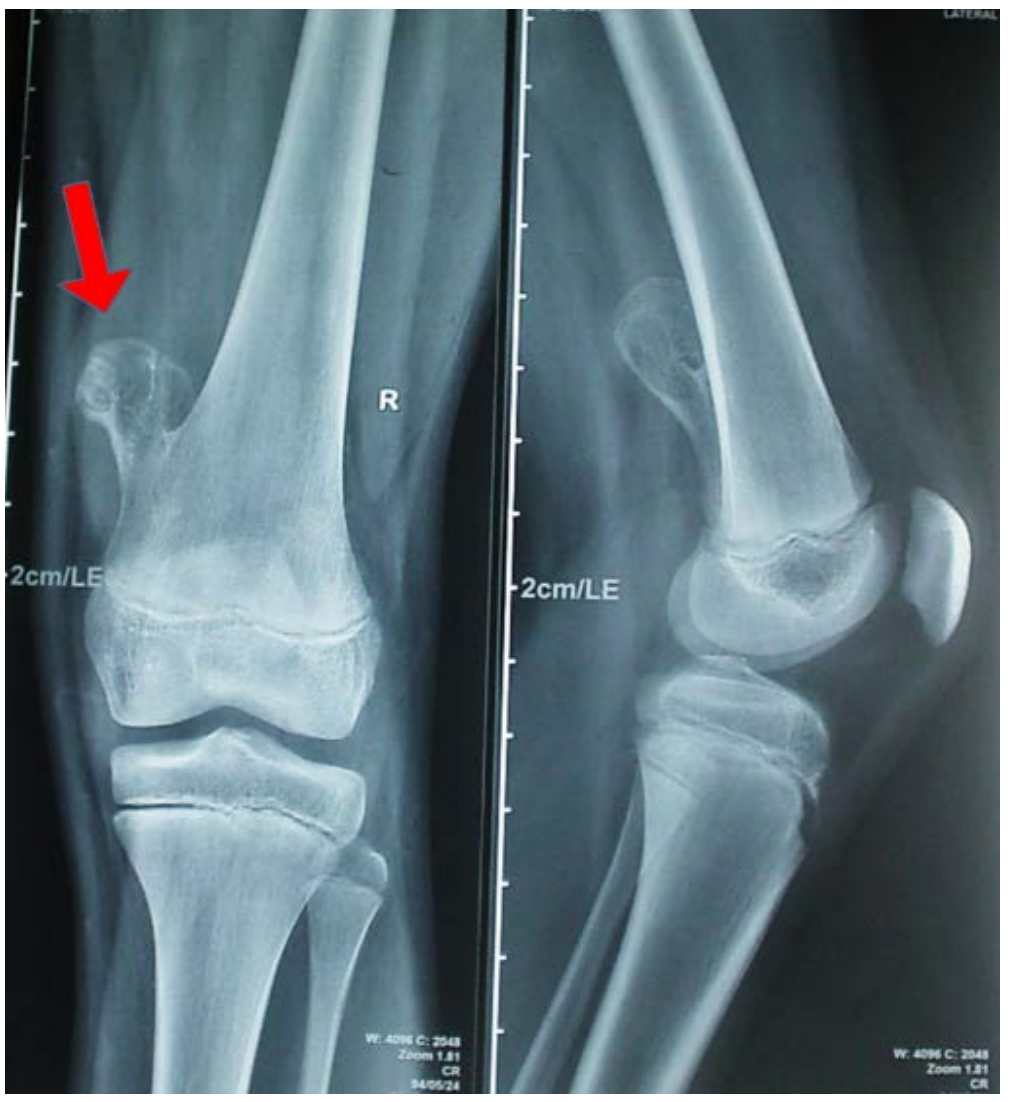

Figure 4. Osteochondroma of the right distal femur

of lesions in the appendicular skeleton and selective resection of lesions in the axial skeleton. The findings of surgery showed a local recurrence rate below $10 \%$ (41). Performing neo-adjuvant chemotherapy and, subsequently, surgical resection in which all tumor cells are completely removed provide a better structure for ambulation or the upper extremity functionality (42). Figure 3 shows a Ewing's sarcoma of the left pelvis.

\section{BENIGN PRIMARY BONE TUMORS}

\section{Osteochondroma}

Most of the benign bone tumors (30\%) are cartilaginous tumors, which are found in tibia and femur. Osteochondroma is commonly seen in the metaphysis and diametaphysis, and it mostly occurs in the above bones $(43,44)$. Solitary osteochondroma (exostosis) mostly occurs at the age of $\geq 40$, while the autosomal and hereditary types of cancer are observed at younger ages with shortened extremities and deformities $(45,46)$. Thick periosteal reaction, endosteal scalloping, and cortical hook are the most reported features. Removing and cutting the tumor by surgery is the best treatment so far (47). Figure 4 shows an osteochondroma of the right distal femur.

\section{Giant cell bone tumor}

Giant cell tumors (GCT) comprise 20\% of benign bone tumors and it mostly presents at ages 20 to $40(48,49)$. It is often presented in long bones, $50-$ $65 \%$ in the area of the knee (50). GCTs are described as huge cells with osteoclast function, which are surrounded by spindle-like stromal and monocytic cells $(51,52)$. They are benign in $80 \%$ of cases. Recurrence after surgical resection is $20-50 \%$, while $10 \%$ of cases may become malignant $(53,54)$. The first-line therapeutic option for this tumor is curettage, followed by bone cement filling. However, this method is highly prone to recurrence (55). Adjuvant treatment, such as zinc chloride, bisphosphonates, phenol, liquid nitrogen and alcohol, is used to reduce the recurrence (56). Wide excision and surgical methods are used for aggressive tumors 


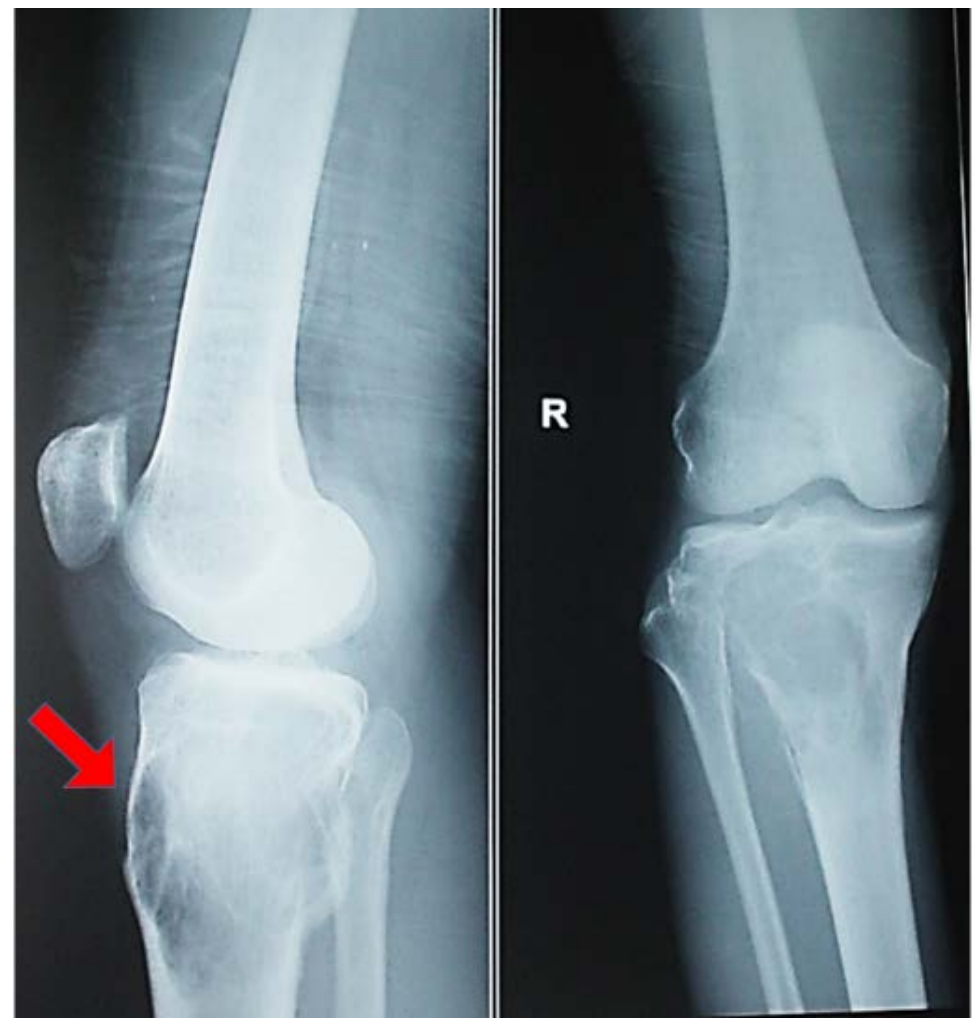

Figure 5. A giant cell tumor of the right proximal tibia

(57). The latest suggestion for the treatment is the use of a chemotherapy drug called denosumab, which is a monoclonal antibody that inhibits the osteoclastic differentiation and activation of GCT by blocking osteoclasts (58). Figure 5 shows a giant cell tumor of the right proximal tibia.

\section{Osteoblastoma}

Another benign bone tumor is called osteoblastoma, which is rare and includes $14 \%$ of bone tumors $(59,60)$. It occurs at ages 20 to 40 (61). Axial skeleton with spinal lesions is the most common site of the tumor (about 33\% of cases), but it may occur in other bones, too (62). The best choice for treatment is medical treatment. Radiotherapy and chemotherapy are the subsequent choices and surgical removal is the last one if the other methods fail. In a few cases, osteoblastoma progressed to osteosarcoma (63,
64). Figure 6 shows an osteoblastoma of the right humerus.

\section{Osteoma}

It is another outgrowth of membranous bones, which is benign and is most prevalent in the paranasal sinuses, skull and long bones (65). It may grow on homoplastic bones and heteroplastic or eteroplastic tissues (43). Osteoma affects osseous tissue, which comprises condensed bone with a welldefined border. It does not have irregular surface or satellite lesions (66). It is difficult to diagnose it if it shows no symptoms. Inflammatory response is considered as one of the underlying mechanisms because its incidence rate is increasing (67). Solitary osteoma is a risk factor for Gardner's syndrome if there are multiple tumors (68). Surgical resection is suggested for symptomatic patients (69). Figure 7 shows an osteoma of the left femur. 


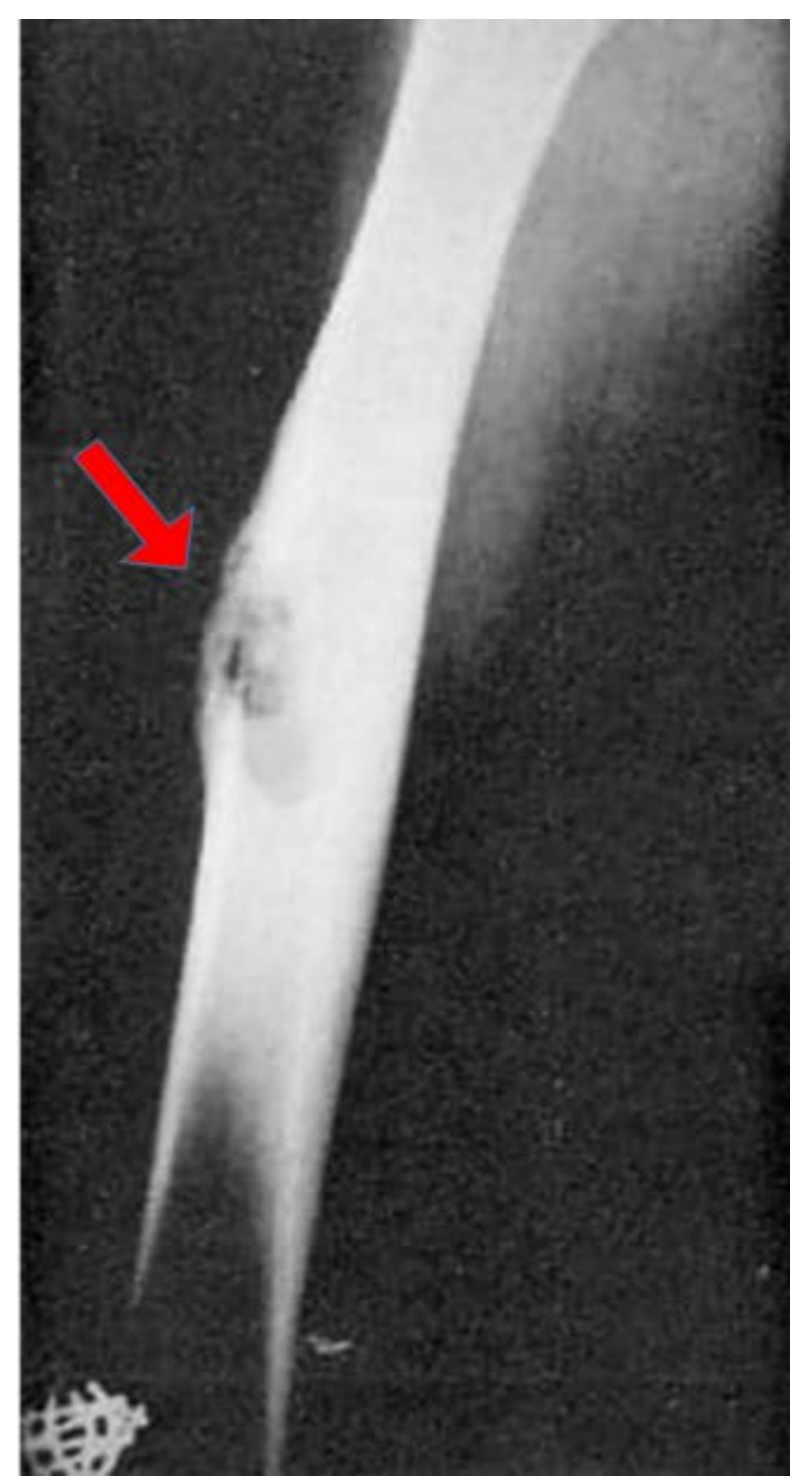

Figure 6. Osteoblastoma of the right humerus

\section{CONCLUSION}

A group of neoplasms, which is prevalent in young adults and children, is bone tumor. These tumors are diagnosed mostly by radiographic evaluations, but it is believed that CT and MRI can be used for detecting the local extent of the tumor. The treatment of benign bone tumors is done mainly in symptomatic patients, or those who are at the risk of pathological fracture and deformity. Surgical removal is the most common treatment for this problem. Active treatment is considered as the best treatment for GCT because there is a risk of malignancy. However, no consensus exists on standards of treatment for most of the benign tumors. Because of their low prevalence, malignant bone tumors are not

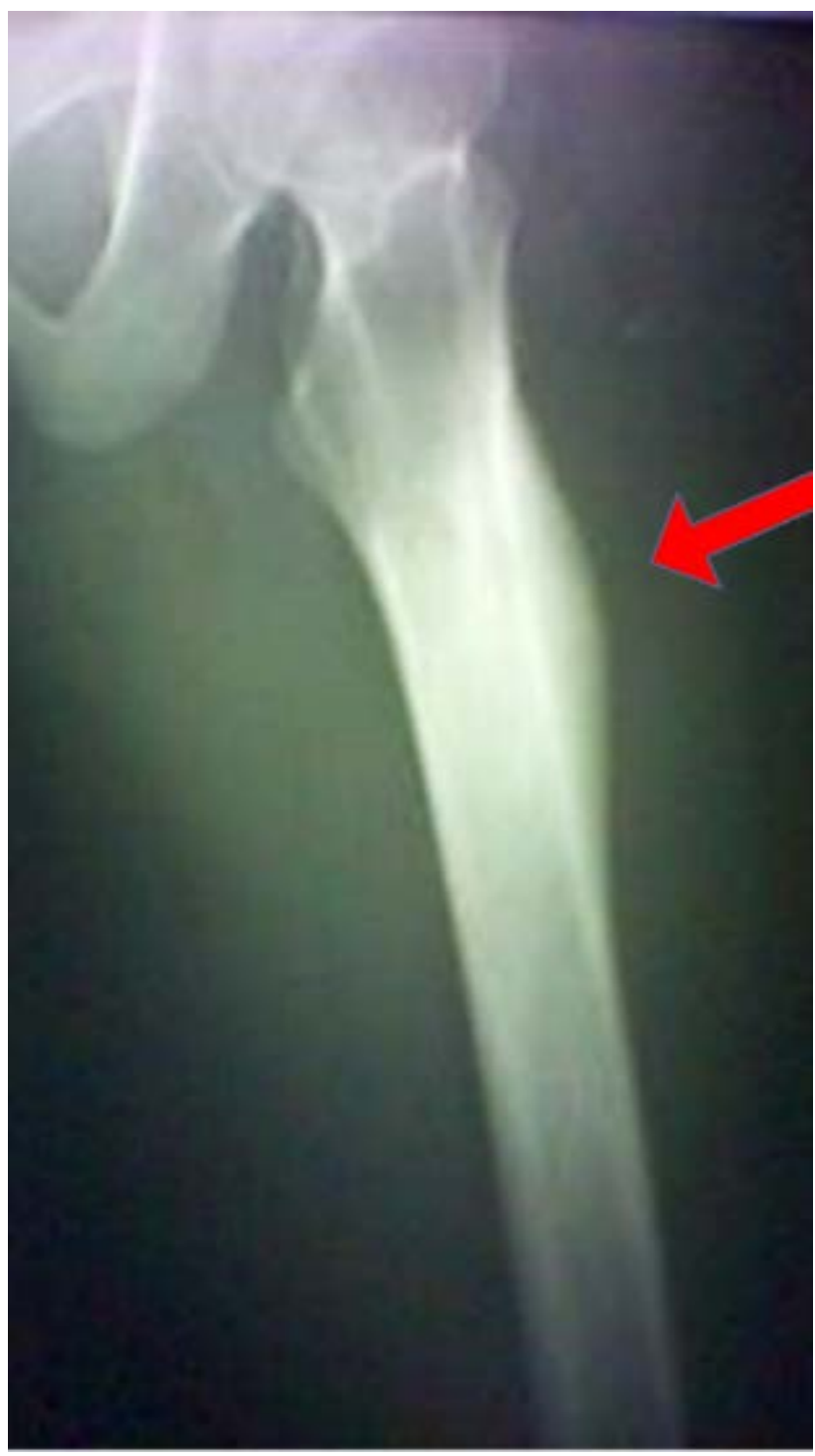

Figure 7. Osteoma of the left femur

easily classified and categorized for the sake of management. Bone malignancies are very important since they are found within the first years of life and, therefore, they can considerably affect the lives of patients and their families. The outcome and survivability of primary malignant bone tumors have improved recently due to both medical and surgical developments. Parallel to this, the molecular and cytogenetic representation have developed significantly, which, combined with light/electron microscopy and immunohistochemical methods, has a contribution to better understanding of these tumors.

\section{Conflicts of interest statement}

Authors declare there is no conflict of interests. 


\section{References}

1. Bollini G, Kalifa C, Panuel M. Malignant bone tumours in children and adolescent. Arch Pediatr. 2006;13(6):669-71.

https://doi.org/10.1016/j.arcped.2006.03.098

2. Macedo F, Ladeira K, Pinho F, et al. Bone metastases: an overview. Oncol Rev.

2017;11(1):321.

https://doi.org/10.4081/oncol.2017.321

3. Vogt A, Schmid S, Heinimann K, et al. Multiple primary tumours: challenges and approaches, a review. ESMO Open. 2017;2(2): e000172.

https://doi.org/10.1136/esmoopen-2017-000172

4. Hauben E, Arends J, Vandenbroucke J, et al. Multiple primary malignancies in osteosarcoma patients. Incidence and predictive value of osteosarcoma subtype for cancer syndromes related with osteosarcoma. Eur J Hum Genet. 2003;11(8):611-8.

https://doi.org/10.1038/sj.ejhg.5201012

5. Jo VY, Fletcher CD. WHO classification of soft tissue tumours: an update based on the 2013 (4th) edition. Pathology. 2014;46(2):95-104. https://doi.org/10.1097/PAT.0000000000000050

6. Plant J, Cannon S. Diagnostic work up and recognition of primary bone tumours: a review. EFORT Open Reviews. 2016;1(6):247-53. https://doi.org/10.1302/2058-5241.1.000035

7. Coindre JM. [New WHO classification of tumours of soft tissue and bone]. Annales de pathologie. 2012;32(5 Suppl):S115-6. https://doi.org/10.1016/j.annpat.2012.07.006

8. Meyers P, Schwartz C, Krailo M, et al. Osteosarcoma: a randomized, prospective trial of the addition of ifosfamide and/or muramyl tripeptide to cisplatin, doxorubicin, and high-dose methotrexate. J Clin Oncol. 2005;23(9):2004-11.

\section{https://doi.org/10.1200/JCO.2005.06.031}

9. Jaffe N. Osteosarcoma: review of the past, impact on the future. The American experience. Cancer Treat Res. 2009;152:239-62. https://doi.org/10.1007/978-1-4419-0284-9 12

10. Chi S, Conklin L, Qin J, et al. The patterns of relapse in osteosarcoma: the Memorial Sloan-Kettering experience. Pediatr Blood Cancer. 2004;42(1):46-51. https://doi.org/10.1002/pbc.10420

11. Patel AA, Ramanathan R, Kuban J, Willis MH. Imaging findings and evaluation of metabolic bone disease. Advances in Radiology. 2015;2015. https://doi.org/10.1155/2015/812794

12. Sandberg A, Bridge J. Updates on the cytogenetics and molecular genetics of bone and soft tissue tumors. Dermatofibrosarcoma protuberans and giant cell fibroblastoma. Cancer Genet Cytogenet. 2003;140(1):1-12.

https://doi.org/10.1016/S0165-4608(02)00848-8

13. Lee EY, Muller WJ. Oncogenes and Tumor Suppressor Genes. Cold Spring Harb Perspect Biol. 2010;2(10): a003236.

https://doi.org/10.1101/cshperspect.a003236

14. Stiewe T, Stanelle J, Theseling C, et al. Inactivation of retinoblastoma (RB) tumor suppressor by oncogenic isoforms of the p53 family member p73. J Biol Chem. 2003;278(16):14230-36.

https://doi.org/10.1074/jbc.M300357200

15. Jaffe N, Carrasco H, Raymond K, et al. Can cure in patients with osteosarcoma be achieved exclusively with chemotherapy and abrogation of surgery? Cancer. 2002;95(10):2202-10.

https://doi.org/10.1002/cncr.10944

16. Ferrari S, Smeland S, Mercuri M, et al. Neoadjuvant chemotherapy with high-dose Ifosfamide, high-dose 
methotrexate, cisplatin, and doxorubicin for patients with localized osteosarcoma of the extremity: a joint study by the Italian and Scandinavian Sarcoma Groups. J Clin Oncol. 2005;23(34):8845-52.

https://doi.org/10.1200/JCO.2004.00.5785

17. Ragland B, Bell W, Lopez R, Siegal G. Cytogenetics and molecular biology of osteosarcoma. Lab Invest. 2002;82(4):365-73.

https://doi.org/10.1038/labinvest.3780431

18. Colding-Rasmussen T, Thorn A, Horstmann P, et al. Survival and prognostic factors at time of diagnosis in high-grade appendicular osteosarcoma: a 21 year single institution evaluation from east Denmark. Acta oncologica (Stockholm, Sweden). 2018;57(3):420-5.

https://doi.org/10.1080/0284186X.2017.1351620

19. Redondo A, Bagué S, Bernabeu D, et al. Malignant bone tumors (other than Ewing's): clinical practice guidelines for diagnosis, treatment and follow-up by Spanish Group for Research on Sarcomas (GEIS). Cancer Chemother Pharmacol. 2017;80(6):1113-31. https://doi.org/10.1007/s00280-017-3436-0

20. Chen $\mathrm{Y}, \mathrm{Wu} \mathrm{P}, \mathrm{Chen} \mathrm{C}, \mathrm{Chen} \mathrm{W}$. Intralesional curettage of central low-grade chondrosarcoma: A midterm follow-up study. J Chin Med Assoc. 2017;80(3):178-82.

https://doi.org/10.1016/j.jcma.2016.10.002

21. Leddy LR, Holmes RE. Chondrosarcoma of bone. Cancer Treat Res. 2014;162:117-30.

https://doi.org/10.1007/978-3-319-07323-1 6

22. Tiet TD, Hopyan S, Nadesan P, et al. Constitutive Hedgehog Signaling in Chondrosarcoma UpRegulates Tumor Cell Proliferation. Am J Pathol. 2006;168(1):321-30.

https://doi.org/10.2353/ajpath.2006.050001

23. van Beerendonk $\mathrm{H}$, Rozeman $\mathrm{L}$, Taminiau $\mathrm{A}$, et al. Molecular analysis of the INK4A/INK4A-ARF gene locus in conventional (central) chondrosarcomas and enchondromas: indication of an important gene for tumour progression. J Pathol. 2004;202(3):359-66.

https://doi.org/10.1002/path.1517
24. Jamil N, Howie S, Salter DM. Therapeutic molecular targets in human chondrosarcoma. Int J Exp Pathol. 2010;91(5):387-93. https://doi.org/10.1111/j.1365-2613.2010.00749.x

25. Sakamoto A. The molecular pathogenesis of dedifferentiated chondrosarcoma. Indian J Orthop. 2014;48(3):262265.

https://doi.org/10.4103/0019-5413.132506

26. Schrage YM, Lam S, Jochemsen AG, et al. Central chondrosarcoma progression is associated with pRb pathway alterations: CDK4 down-regulation and p16 overexpression inhibit cell growth in vitro. J Cell Mol Med. 2009;13(9a):2843-52. https://doi.org/10.1111/j.1582-4934.2008.00406.x

27. Chow WA. Chondrosarcoma: biology, genetics, and epigenetics. F1000Research. 2018;7:F1000. https://doi.org/10.12688/f1000research.15953.1

28. Trieb K, Sulzbacher I, Kubista B. Recurrence rate and progression of chondrosarcoma is correlated with heat shock protein expression. Oncol Lett. 2016;11(1):521-4. https://doi.org/10.3892/ol.2015.3926

29. Dickey I, Rose P, Fuchs B, et al. Dedifferentiated chondrosarcoma: the role of chemotherapy with updated outcomes. J Bone Joint Surg Am. 2004;86(11):2412-18. https://doi.org/10.2106/00004623-200411000-00008

30. Mitchell A, Ayoub K, Mangham D, Grimer R, et al. Experience in the treatment of dedifferentiated chondrosarcoma. J Bone Joint Surg Br. 2000;82(1):55-61.

https://doi.org/10.1302/0301-620X.82B1.0820055

31. Rodríguez-Galindo C, Navid F, Liu Tet al. Prognostic factors for local and distant control in Ewing sarcoma family of tumors. Ann Oncol. 2008;19(4):814-20. https://doi.org/10.1093/annonc/mdm521

32. Kim S, Park Y. Ewing sarcoma: a chronicle of molecular pathogenesis. Hum Pathol. 2016;55:91100.

https://doi.org/10.1016/j.humpath.2016.05.008 
33. Franchi A, Pasquinelli G, Cenacchi G, et al. Immunohistochemical and ultrastructural investigation of neural differentiation in Ewing sarcoma/PNET of bone and soft tissues. Ultrastruct Pathol. 2001;25(3):219-25. https://doi.org/10.1080/01913120120194

34. Toomey EC, Schiffman JD, Lessnick SL. Recent Advances in the Molecular Pathogenesis of Ewing's Sarcoma. Oncogene. 2010;29(32):4504-16. https://doi.org/10.1038/onc.2010.205

35. Lessnick S, Dacwag C, Golub T. The Ewing's sarcoma oncoprotein EWS/FLI induces a p53dependent growth arrest in primary human fibroblasts. Cancer Cell. 2002;1(4):393-401.

\section{https://doi.org/10.1016/S1535-6108(02)00056-9}

36. Taylor C, Patel K, Jones $\mathrm{T}$, et al. Diagnosis of Ewing's sarcoma and peripheral neuroectodermal tumour based on the detection of $t(11 ; 22)$ using fluorescence in situ hybridisation. Br J Cancer. 1993;67(1):128-33.

https://doi.org/10.1038/bjc.1993.22

37. Kovar H. Ewing's sarcoma and peripheral primitive neuroectodermal tumors after their genetic union. Curr Opin Oncol. 1998;10(4):334-42. https://doi.org/10.1097/00001622-199807000-00010

38. Tirode F, Laud-Duval K, Prieur A, et al. Mesenchymal stem cell features of Ewing tumors. Cancer Cell. 2007;11(5):421-9. https://doi.org/10.1016/j.ccr.2007.02.027

39. Grier H, Krailo M, Tarbell N, et al. Addition of ifosfamide and etoposide to standard chemotherapy for Ewing's sarcoma and primitive neuroectodermal tumor of bone. N Engl J Med. 2003;348(8):694-701. https://doi.org/10.1056/NEJMoa020890

40. Picci P, Rougraff B, Bacci G, et al. Prognostic significance of histopathologic response to chemotherapy in nonmetastatic Ewing's sarcoma of the extremities. Journal of clinical oncology: official joJ Clin Oncol. 1993;11(9):1763-9. https://doi.org/10.1200/JCO.1993.11.9.1763

41. Bacci G, Longhi A, Briccoli A, et al. The role of surgical margins in treatment of Ewing's sarcoma family tumors: experience of a single institution with 512 patients treated with adjuvant and neoadjuvant chemotherapy. Int J Radiat Oncol Biol Phys. 2006;65(3):766-72.

https://doi.org/10.1016/j.ijrobp.2006.01.019

42. Bacci G, Forni C, Longhi A, et al. Long-term outcome for patients with non-metastatic Ewing's sarcoma treated with adjuvant and neoadjuvant chemotherapies. 402 patients treated at Rizzoli between 1972 and 1992. Eur J Cancer. 2004;40(1):73-83. https://doi.org/10.1016/j.ejca.2003.08.022

43. Hakim DN, Pelly T, Kulendran M, Caris JA. Benign tumours of the bone: A review. J Bone Oncol. 2015;4(2):37-41.

https://doi.org/10.1016/j.jbo.2015.02.001

44. Palmer F, Blum P. Osteochondroma with spinal cord compression: report of three cases. J Neurosurg. 1980;52(6):842-5.

https://doi.org/10.3171/jns.1980.52.6.0842

45. Kenney P, Gilula L, Murphy W. The use of computed tomography to distinguish osteochondroma and chondrosarcoma. Radiology. 1981;139(1):129-37. https://doi.org/10.1148/radiology.139.1.6937887

46. Woertler K, Lindner N, Gosheger G, et al. Osteochondroma: MR imaging of tumor-related complications. Eur Radiol. 2000;10(5):832-40. https://doi.org/10.1007/s003300051014

47. Herget GW, Kontny U, Saueressig U, et al. [Osteochondroma and multiple osteochondromas: recommendations on the diagnostics and followup with special consideration to the occurrence of secondary chondrosarcoma]. Der Radiologe. 2013;53(12):1125-36.

https://doi.org/10.1007/s00117-013-2571-9

48. Turcotte R. Giant cell tumor of bone. Orthop Clin North Am. 2006;37(1):35-51.

https://doi.org/10.1016/j.ocl.2005.08.005

49. Chakarun C, Forrester D, Gottsegen C, et al. Giant cell tumor of bone: review, mimics, and new developments in treatment. Radiographics: a review publication of the Radiological Society of North America, Inc. 2013;33(1):197-211. https://doi.org/10.1148/rg.331125089 
50. Szendröi M. Giant-cell tumour of bone. J Bone Joint Surg Br. 2004;86(1):5-12. https://doi.org/10.1302/0301-620X.86B1.14053

51. Levine E, De Smet A, Neff J, Martin N. Scintigraphic evaluation of giant cell tumor of bone. AJR Am J Roentgenol. 1984;143(2):343-8. https://doi.org/10.2214/ajr.143.2.343

52. van der Heijden L, Dijkstra PS, Campanacci DA, et al. Giant Cell Tumor With Pathologic Fracture: Should We Curette or Resect? Clin Orthop Relat Res. 2013;471(3):820-9. https://doi.org/10.1007/s11999-012-2546-6

53. Manohar K, Mittal BR, Bhattacharya A, Sen R. Recurrent giant cell tumor of foot detected by F18FDG PET/CT. Indian J Nucl Med. 2012;27(4):262-3. https://doi.org/10.4103/0972-3919.115402

54. Zhen W, Yaotian H, Songjian L, et al. Giant-cell tumour of bone. The long-term results of treatment by curettage and bone graft. J Bone Joint Surg Br. 2004;86(2):212-6. https://doi.org/10.1302/0301-620X.86B2.14362

55. Yang $T$, Zheng $X$, Lin $X$, Yin Q. Postoperative irrigation with bisphosphonates may reduce the recurrence of giant cell tumor of bone. Med Hypotheses. 2013;81(5):851-2.

https://doi.org/10.1016/j.mehy.2013.08.002

56. Zuo D, Zheng L, Sun W, et al. Z. Contemporary adjuvant polymethyl methacrylate cementation optimally limits recurrence in primary giant cell tumor of bone patients compared to bone grafting: a systematic review and meta-analysis. World J Surg Oncol. 2013;11:156.

https://doi.org/10.1186/1477-7819-11-156

57. Malawer M, Bickels J, Meller I,et al. Cryosurgery in the treatment of giant cell tumor. A long-term followup study. Clin Orthop Relat Res. 1999(359):176-88.

https://doi.org/10.1097/00003086-199902000-00019

58. Chawla S, Henshaw R, Seeger L, et al. Safety and efficacy of denosumab for adults and skeletally mature adolescents with giant cell tumour of bone: interim analysis of an open-label, parallelgroup, phase 2 study. Lancet Oncol.
2013;14(9):901-8. https://doi.org/10.1016/S1470-2045(13)70277-8

59. Anania P, Fiaschi P, Merciadri P, et al. Case of Spinal Osteoblastoma in Elderly: Is It Really a Young Patient's Disease? World neurosurgery. 2018;112:243-6.

https://doi.org/10.1016/j.wneu.2018.01.180

60. Caufourier C, Leprovost N, Guillou-Jamard M, et al. Benign bone forming tumors. Rev Stomatol Chir Maxillofac. 2009;110(4):202-8. https://doi.org/10.1016/j.stomax.2009.06.008

61. Davis N, Dooley B. Benign osteoblastoma. Aust N Z J Surg. 1976;46(1):37-43.

https://doi.org/10.1111/j.1445-2197.1976.tb03190.x

62. Greenspan A. Benign bone-forming lesions: osteoma, osteoid osteoma, and osteoblastoma. Clinical, imaging, pathologic, and differential considerations. Skeletal radiology. 1993;22(7):485500 .

https://doi.org/10.1007/BF00209095

63. Schajowicz F, Lemos C. Osteoid osteoma and osteoblastoma. Closely related entities of osteoblastic derivation. Acta Orthop Scand. 1970;41(3):272-91.

https://doi.org/10.3109/17453677008991514

64. Lucas D. Osteoblastoma. Arch Pathol Lab Med. 2010;134(10):1460.

https://doi.org/10.1039/b925938b

65. Hagiwara A, Nagai N, Ogawa Y, Suzuki M.

Osteoma of the Pharynx That Developed from the Hyoid Bone. Case Rep Otolaryngol. 2014;2014: 732096.

https://doi.org/10.1155/2014/732096

66. Silva B, Bueno M, Yamamoto-Silva F, et al. Differential diagnosis and clinical management of periapical radiopaque/hyperdense jaw lesions. Braz Oral Res. 2017;31:e52. https://doi.org/10.1590/1807-3107bor-2017.vol31.0052

67. Sayan N, Uçok C, Karasu H, Günhan O. Peripheral osteoma of the oral and maxillofacial region: a study of 35 new cases. J Oral Maxillofac 
Surg. 2002;60(11):1299. https://doi.org/10.1053/joms.2002.35727

68. Tawab HMA, Kumar R, Tabook SMS. Osteoma Presenting as a Painless Solitary Mastoid Swelling. Case Rep Otolaryngol. 2015;2015: 590783. https://doi.org/10.1155/2015/590783

69. da Costa E, Peyneau P, Ferreira L, et al. Clinical implications, diagnosis, and treatment of a giant frontoethmoid osteoma. Gen Dent. 2018;66(5):e1-e4.

\title{
Pregled karakteristika i lečenja benignih i malignih tumora kostiju
}

\author{
Masoud Bahrami Frydoni1,2,3, Seyed Mokhtar Esmaeilnejad-Ganji1,2,3 \\ ${ }^{1}$ Centar za istraživanje oštećenja pokretliivosti, Institut za ispitivanje zdravlja, \\ Univerzitet medicinskih nauka u Babolu, Babol, Iran \\ ${ }^{2}$ Klinički centar za istraživanje i razvoj, Bolnica Shahid Beheshti, Univerzitet medicinskih nauka u Babolu, \\ Babol, Iran \\ ${ }^{3}$ Departman za ortopediju, Medicinski fakultet, Univerzitet medicinskih nauka u Babolu, \\ Babol, Iran
}

\section{S A ŽETAK}

Tumori kostiju, uključujući benigne i maligne lezije, ne metastaziraju. Međutim, mogu se pojaviti u bilo kom delu skeleta. Najčešće se javljaju na distalnom delu femura i proksimalnom delu tibije. Većina benignih tumora zahvata hrskavice i zovu se osteohondromi. Na osnovu dosadašnjih izveštaja, benigni tumori kostiju češće se javljaju od primarnih malignih tumora. Maligni tumori kostiju pripadaju drugom tipu tumora kostiju i najčešće se javljaju u prvim godinama života. Iz tog razloga, značajno utiču na opšte stanje bolesnika i život njegove porodice. Ovi tumori obuhvataju osteosarkom, hondrosarkom i Juingov (Ewing) sarkom. U ovom radu prikazani su epidemiologija, karakteristike, i lečenje najvažnijih tipova benignih i malignih tumora kostiju. Ovi podaci biće korisni lekarima, kao i ostalim zdravstvenim radnicima, kako bi bolje razumeli tumore kostiju i njihovo lečenje.

Ključne reči: tumor kostiju, maligni tumor, benigni tumor 